\title{
MEDICAL SERVICE IN INDUSTRY IN THE U.S.S.R.*
}

\author{
BY \\ AUGUST LETAVET \\ Obukh Central Institute of Labour Hygiene and Occupational Diseases, Moscow?
}

Many of the largest war factories in Russia have had to be transferred to remote districts, where proper arrangements had to be made for the accommodation of large numbers of workers in conditions such as to promote maximum output and reduce the incidence of disease of all kinds, including special industrial hazards. According to G. A. Mitarev 'there are three main problems of health protection in war-time; firstly, to establish hospitals so as to secure the efficient rehabilitation of men of the Red Army; secondly, to combat epidemics; and, thirdly, to provise good medicosanitary services for war factory workers.'

\section{Organization of Medico-Sanitary Services in War Factories}

A 'Medico-Sanitary Administration' (M.S.A.) was set up in each war factory to co-ordinate the medical services available for the workers, and sometimes also for their families. This Administration usually comprised a 'Polyclinic' with specialist departments, ambulance posts staffed by doctors or nurses in the larger shops, and pathological laboratories. Special hospitals were provided for the larger factories if local hospital facilities were insufficient. All factories came under the control of the State Industrial Sanitary (S.I.S.) Inspection Administration. The work of the M.S.A. includes hospital treatment, first aid, domiciliary visits, and factory inspection. Full records are kept of sickness and accidents, preventive measures applied, and health education of workers carried out. The M.S.A. co-operates closely with trade unions and social workers, who meet on joint committees.

\section{Industrial Hygiene Research Institutions}

There are now five special institutions for research in industrial medicine in the Soviet Union, viz.:

1. The Obukh Central Institute of Labour Hygiene and Occupational Diseases, Moscow.

2. The Ukrainian Institute of Hygiene, now working at Novosibirsk.

3. The Institute of Labour Hygiene and Occupational Diseases, Leningrad.

4. The Urals Institute of Labour Hygiene, Sverdlovsk. * Condensed by D. C. Norris from a translation kindly lent by
5. The Institute of Labour Hygiene and Occupational Diseases, Gorky.

The first of these, and the largest, was founded in Moscow in 1923 by V. A. Obukh, then head of the Public Health Board for Moscow and district. The present Director is Professor Z. B. Smelyansky. The Institute includes a clinic for industrial diseases, in charge of Professor S. M. Genkin, with accommodation for 200 patients, and with biochemical, pathological and other laboratories. The large Hygiene Department (under control of the present writer) has laboratories for the study of industrial physiology and toxicology, dust hazards and ventilation; as well as meteorological and physico-chemical laboratories. The Ukrainian and the Urals Institutes deal mainly with coal and iron industries, and the Gorky Institute with the chemical industries. In spite of the blockade, the Leningrad Institute has never ceased to carry on research work, as well as dealing with special local problems such as the hygiene of bomb shelters and the prophylaxis of frost-bite.

\section{Ventilation Problems}

Black-out arrangements in factories sometimes led to overheating, especially during the hot summer weather, while removal of noxious fumes became more difficult. Shops were fitted with venetian blinds, labyrinths, shields, etc., while in the 'heat shops' (open-hearth furnaces, rolling mills, forging and casting shops, etc.) ' air showers' were installed. Loss of sodium chloride in the sweat was corrected by provision of unlimited supplies of soda-water containing $0.3-0.5$ per cent. of table salt.

\section{Industrial Toxicology}

The Obukh Institute has issued leaflets dealing with prevention of industrial poisoning, and M.S.A. personnel have been instructed in risks of materials such as T.N.T. Routine medical examination of all workers in T.N.T. is compulsory, and especially susceptible persons are transferred to other work. The Obukh Institute has devised methods of dealing with the risk of electric welding in tanks and other confined spaces. This is liable to set up asthma and bronchitis from inhalation of dust and toxic gases. Legislation was introduced in 1942 to reduce toxic hazards by hermetical enclosure of 
machines, efficient transportation of dust-forming substances and by application of wet methods of boring, crushing, grinding, and polishing. Regulations control the maximum permissible concentration of toxic substances in the air of factories.

\section{Supply of Vitamin C}

Where large numbers of workers were moved to new localities there was often great difficulty in providing adequate amounts of fresh vegetables. Deficiency of vitamin $\mathrm{C}$ was made up by giving extracts of Ural pine or fir needles, or infusions of Siberian pine or larch, containing often as much as 200-300 mg. of ascorbic acid per $100 \mathrm{gm}$. of pine needles.

\section{Health of Women Workers}

There has been a great increase in the number of women factory workers. They showed, generally speaking, a lower incidence of accidents and of skin infections-probably owing to their greater attention to safety regulations and better personal hygiene than men. Excluding absence for pregnancy, or to attend to sick children, they showed also a lower sickness rate than men. On the other hand, they were slightly more susceptible to industrial poisoning, especially by T.N.T. Special medical services for women have been set up in many factories, including gynaecological and antenatal clinics, day nurseries and 'Feminine hygiene rooms' in some of the larger plants.

Under the stress of war the aim of Soviet industrial hygiene has been to reduce occupational risks and prevent sickness among factory workers, and to conduct experimental and theoretical research on various problems of industrial hygiene and toxicology, and thus to contribute to the advance of science as a whole and to the effort of the Soviet people to defend their country and expel the Hitlerite invaders.

\title{
HEATING AND VENTILATION : REQUIREMENTS AND METHODS
}

\author{
Addendum to Paper by T. BEDFORD. (This Journal, Vol. I, No. 1, p. 31)
}

On p. 35 reference was made to the scale of equivalent warmth, derived by Bedford (1936), by which the combined effects of the four factors which make up the thermal environment can be expressed in a single figure. The equivalent warmth was defined as the temperature of a uniform enclosure, with air and surroundings at the same temperature, and with the air still and saturated with water vapour, which would produce a sensation of warmth equal to that evoked by the combination of radiation and air temperature, velocity and humidity in question.

Through an oversight no mention was made of two other developments concerning the concept of equivalent warmth. Dufton (1936) proposed that the scale should be referred to semi-saturated and not saturated air, mainly on the ground that under extreme humidity conditions there is a difference between sensations of warmth and of comfort.
This view was taken later by the Joint Committee (of the Medical Research Council and the Department of Scientific and Industrial Research) on Research in Heating and Ventilation, which provisionally defined the equivalent warmth of an environment as 'that temperature of a uniform enclosure in which, in semi-saturated air, equal warmth would be experienced' (Douglas, 1938).

In his 1936 paper, Dufton gave a chart which, in the absence of appreciable radiation, enables equivalent warmth to be determined for various temperatures, humidities and degrees of air movement.

\section{REFERENCES}

Bedford, T. (1936). Indust. Hlth. Res. Bd. Rept. No. 76.

Douglas, C. G. (1938). App. I to Rept. of the Building Research Board for the year 1937.

Dufton, A. F. (1936). J. Instn. Heat. \& Vent. Engrs., 4, 181 . 